\title{
Letter to the Editor: Human infections with avian influenza A(H7N9) in China: preliminary assessments of the age and sex distribution
}

Viroj Wiwanitkita

$\mathrm{T}$ he recent report on human infections with avian influenza $A(\mathrm{H} 7 \mathrm{~N} 9)$ is very interesting. ${ }^{1}$ The age distribution of the patients was studied, and Arima et al. mentioned that "it seems unlikely that elderly men are being overly selected." ${ }^{1}$ It is true that the virus can attack any age group. The things that determine vulnerability to infection in each age group include (1) immunity to infection, (2) exposure to the disease, (3) availability of medical care, and (4) ability of medical personnel to diagnosis the illness.

The elderly are more prone to infections due to their weaker health status as compared to the young. In addition, the high number of infections among the elderly might imply that they have no previous immunity to the infection, indicating that avian influenza $A(H 7 N 9)$ is a new infection for the Chinese in our generation (compared to swine flu in which there was evidence of cross-protective immunity among the elderly that might relate to the low number of cases among that group ${ }^{2}$.

\section{Conflicts of interest}

None declared.

Funding

None.

\section{References}

1. Arima Y, Vong S; World Health Organization Outbreak Response Team. Human infections with avian influenza $A(H 7 N 9)$ virus in China: preliminary assessments of the age and sex distribution. Western Pacific Surveillance and Response Journal, 2013, 4(2): 1-3.doi: 10.5365/wpsar.2013.4.2.005 pmid:24015363

2. De Marco MA et al. Evidence of cross-reactive immunity to 2009 pandemic influenza A virus in workers seropositive to swine H1N1 influenza viruses circulating in Italy. PLOS ONE, 2013, 8:e57576. doi:10.1371/journal.pone.0057576 pmid:23469029

a Hainan Medical University, People's Republic of China (e-mail: wviroj@yahoo.com) Submitted: 13 September 2013; Published: 00 October 2013

doi: 10.5365/wpsar.2013.4.3.006 